\title{
AUSTRALIAN GUIDELINES FOR WATER RECYCLING - SETTING HEALTH BASED PERFORMANCE TARGETS AND SAFE USE OF WASTEWATER
}

\section{David Cunliffe}

Government of South Australia - SA Health

Adelaide, Australia

\section{Susan Petterson}

Water \& Health Pty Ltd.

Griffith University

Corlette, Australia 


\section{Copyright:}

\section{cc) (1) (2) \\ BY SA}

This publication is available in Open Access under the Attribution-ShareAlike 3.0 IGO (CC-BY-SA 3.0 IGO) license (http://creativecommons.org/licenses/by-sa/3.0/igo). By using the content of this publication, the users accept to be bound by the terms of use of the UNESCO Open Access Repository (http://www.unesco.org/openaccess/terms-use-ccbysa-en).

\section{Disclaimer:}

The designations employed and the presentation of material throughout this publication do not imply the expression of any opinion whatsoever on the part of UNESCO concerning the legal status of any country, territory, city or area or of its authorities, or concerning the delimitation of its frontiers or boundaries. The ideas and opinions expressed in this publication are those of the authors; they are not necessarily those of UNESCO and do not commit the Organization.

\section{Citation:}

Cunliffe, D. and Petterson, S. (2019). Australian guidelines for water recycling - setting health based performance targets and safe use of wastewater. In: J.B. Rose and B. Jiménez-Cisneros, (eds) Water and Sanitation for the 21st Century: Health and Microbiological Aspects of Excreta and Wastewater Management (Global Water Pathogen Project). (S. Petterson and G. Medema (eds) Part 5: Case Studies), Michigan State University, E. Lansing, MI, UNESCO. https://doi.org/10.14321/waterpathogens.74

Acknowledgements: K.R.L. Young, Project Design editor; Website Design (http://www.agroknow.com) 


\section{Summary}

\section{Highlights}

- A fit-for-purpose approach for all forms of water recycling is presented

- End uses range from drip-irrigation of trees to potable reuse
- Considers risk reduction provided by treatment and non-treatment measures

- Applies to all sizes of schemes from small rural to large urban schemes

- Addresses reuse of treated sewage and greywater and treated and untreated stormwater

- Accessible and usable by operators of all types of recycled water schemes

\section{Graphical abstract}
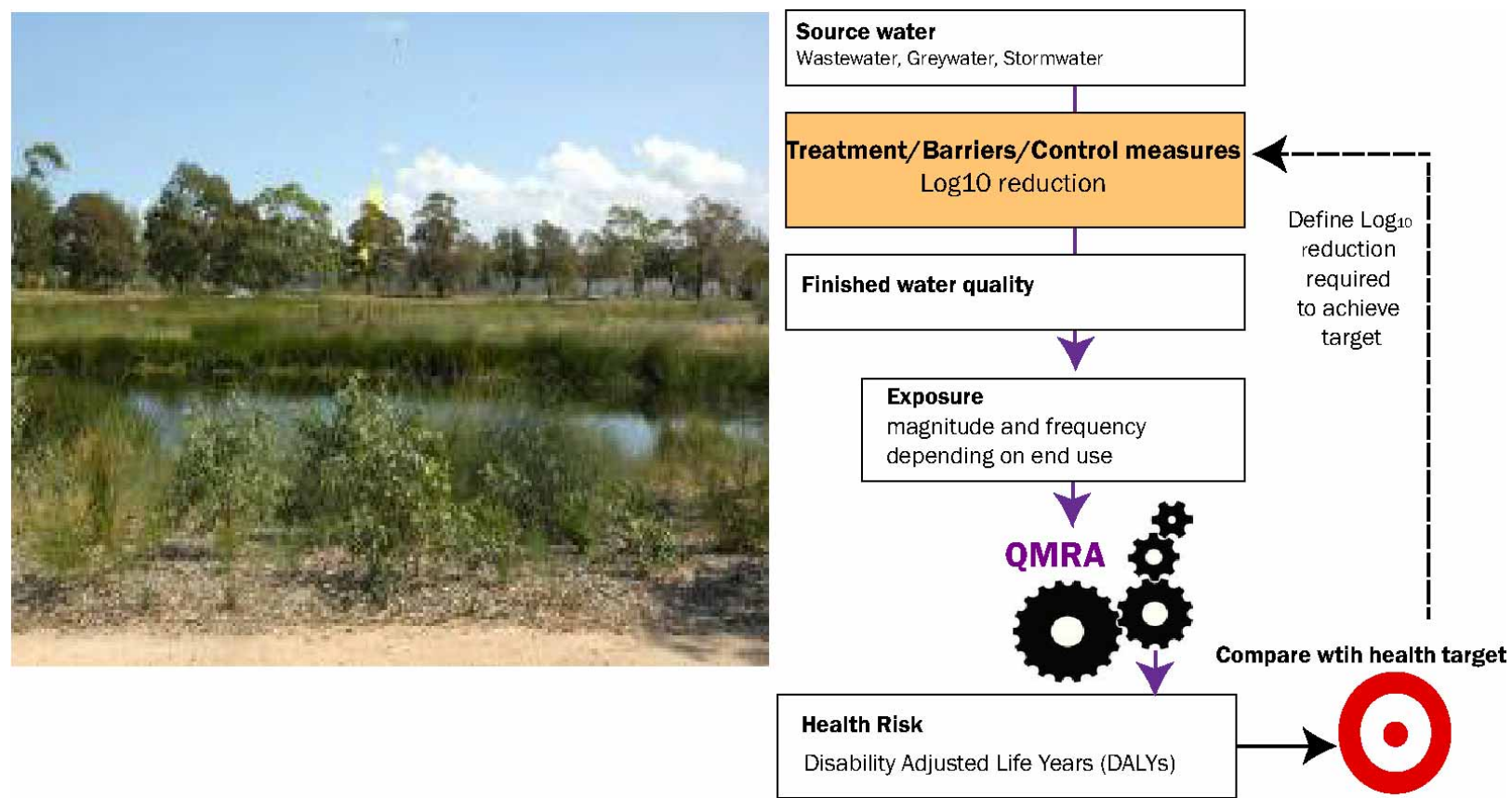

Figure 1. Example of urban wetland used for treatment of stormwater (left) and illustration of QMRA framework as applied to achieve fit-for-purpose water reuse (right)

\section{Management objective}

The lack of comprehensive national recycled water guidelines was identified as a barrier to increasing use of wastewater, greywater and stormwater. To remove this barrier a set of guidelines was developed, as part of the Australian National Water Quality Management Strategy, to provide clear direction to scheme developers and regulators on how to design, manage and operate recycled water schemes safely and sustainably. The objective was to provide guidelines that are flexible and provide a fit-forpurpose water quality approach that applies to all forms and sizes of recycled water schemes ranging from small rural to large urban schemes. The guidelines apply to enduses ranging from drip irrigation of woodlots, to urban and agricultural irrigation and potable re-use.

\section{Location and Setting}

In Australia, as experienced in much of the world, the beginning of the $21^{\text {st }}$ century has been characterised by increased pressure on freshwater supplies in all large cities and most regional areas. This pressure is likely to increase in response to climate variability and population growth. It was identified that traditionally underutilised wastewater, grey water and stormwater need to be considered as valuable water resources that can either supplement or replace drinking water supplies. 


\section{Outcome and Recommendations}

The guidelines were developed to provide practical guidance on designing, managing and operating recycled water schemes with a focus on defining water quality requirements that are fit-for-purpose. From a public health perspective, within a risk management framework, the focus was to identify microbial performance targets in the form of $\log _{10}$ reductions of enteric pathogens taking into account the type of source water and the intended end use.

The targets for all forms of recycled water use were developed using a QMRA based approach. The methodology adopted in the guidelines was necessarily conservative without being overly restrictive; many of the QMRA assumptions, and expected reductions achieved by different barriers encapsulated considerable uncertainty. However, the QMRA provided a structured quantitative framework to allow for a diverse range of potential recycled water uses to be evaluated. Most importantly, the approach allowed for appropriate combinations of treatment and non-treatment options to ensure safe use of recycled water.
The guidelines include $\log _{10}$ reduction targets for various uses of wastewater, greywater and stormwater and provide a process for determining targets for alternative end-uses. The guidelines then describe how these targets can be achieved using treatment and non-treatment options. Use of non-treatment options reduces the focus on treatment and can reduce the cost of recycled water schemes. $\log _{10}$ reduction credits are assigned for nontreatment options based on exposure reductions achieved by options such as crop restrictions and irrigation restrictions (e.g. drip irrigation rather than spray irrigation, night time only irrigation).

Examples are included in the following two case studies (http://www.waterpathogens.org/book/building-a-saferec y c led - water-scheme and http://www.waterpathogens.org/book/how-do-I-ensure-myexisting-recycled-water-scheme-is-safe)

For a more complete summary, see case study 5 of the WHO (2016) Quantitative Microbial Risk Assessment: application for Water Safety Management, http://www.who.int/water sanitation health/publications/q mra/en/. World Health Organization, Geneva. (attach PDF)

The full guideline document can be found at https://nhmrc.gov.au/about-us/publications/australian-guide lines-water-recycling 